\section{Japanese Snowbell Exhibits Variability for Time of Vegetative Budbreak and Susceptibility to Spring Freeze Damage}

Sandra M. Reed ${ }^{1}$

Floral and Nursery Plants Research Unit, U.S. National Arboretum, Agricultural Research Service, U.S. Department of Agriculture, Tennessee State University Nursery Research Center, 472 Cadillac Lane, McMinnville, TN 37110

Additional index words. Styrax japonicus, dormancy, plant breeding

\begin{abstract}
Japanese snowbell (Styrax japonicus Sieb. \& Zucc.) is an outstanding small ornamental tree that is underused in the U.S. One of the reasons this Asian native is not more widely planted is that it is subject to spring freeze damage. The objectives of this study were to determine if there was variability within $S$. japonicus for time of budbreak and if this variability could be used for selecting plants better adapted to areas of the country that frequently experience late spring freezes. During Spring 1999 and 2000, budbreak was evaluated weekly in 224 open-pollinated seedlings. While weather conditions varied greatly between the 2 years, there was good consistency between 1999 and 2000 data. There was a 4-week difference between the earliest and latest plants to break dormancy. Based on the 1999 and 2000 data, 28 plants were selected and propagated. A replicated trial involving these selections and three cultivars was carried out in 2002, 2003 and 2004. All of the selections broke bud later and suffered less freeze damage than the cultivars 'Emerald Pagoda' and 'Carillon', but many performed similarly to 'Pink Chimes'. Variation in height, width, caliper and canopy shape was observed among the selections. There is an opportunity to utilize the genetic variability in $S$. japonicus for developing cultivars with reduced susceptibility to spring freeze damage.
\end{abstract}

Styrax japonicus (Japanese snowbell) is a small deciduous tree that is cultivated as an ornamental. Native to Japan, China, Korea, Taiwan and the Philippines, it was introduced into the U.S. in 1862 (Dirr, 1998). The species grows from 6 to $9 \mathrm{~m}$ in height with a similar spread, making it a valuable plant for use in small residential landscapes or under utility lines. Flowers are bell-shaped, about $2 \mathrm{~cm}$ in diameter, and very fragrant. They are produced in midspring and hang beneath the foliage in three- to six-flowered racemes. Foliage is medium to dark green in summer and may turn yellow in fall. The species is generally pest free, even though problems with Ambrosia beetles, Xylosandrus spp., have been reported (C.E. Tubesing, 1990, D. Shadow, Shadow Nursery, personal communication). Styrax japonicus is rated as hardy to USDA cold hardiness Zone 5.

A few cultivars of $S$. japonicus are commercially available in the U.S. (Dirr, 1998; Raulston, 1991). 'Issai' is a fast-growing cultivar that that roots easily. 'Carillon' has a weeping plant habit and grows to only 2.5 to 4 $\mathrm{m}$ in height. 'Pink Chimes' is a pink-flowered selection that forms an upright shrub or small tree. These three cultivars were introduced to the U.S. from Japan. 'Emerald Pagoda' was collected in Korea and has leaves that are two to

Received for publication 1 Dec. 2004. Accepted for publication 11 Dec. 2004. Mention of trade names of commercial products in the publication is solely for the purpose of providing specific information and does not imply recommendation or endorsement by the U.S. Department of Agriculture.

${ }^{1}$ Research geneticist.
Mont.). The field consisted of a Waynesboro silt loam with a $\mathrm{pH}$ of 5.5. Within-row spacing was $1.2 \mathrm{~m}$ and between-row spacing was $1.8 \mathrm{~m}$. Plants were fertilized each spring at the rate of $57 \mathrm{~kg} \cdot \mathrm{ha}^{-1} \mathrm{~N}$. Drip irrigation was provided as needed throughout the growing season.

Plants were evaluated in Spring 1999 and 2000 for budbreak, which was rated on a scale of 0 to 5 , where $0=0 \%, 1=1 \%$ to $10 \%, 2=11 \%$ to $25 \%, 3=26 \%$ to $50 \%, 4=51 \%$ to $75 \%$, and $5=76 \%$ to $100 \%$ of the buds on a plant having broken dormancy. A bud was considered to have broken dormancy when the overlapping bud scales had separated enough to reveal leaves. Plants were rated weekly for 6 weeks beginning when budbreak was first observed on any of the seedlings. Weekly budbreak ratings were averaged and Pearson's correlation coefficient was calculated to determine the consistency of 1999 and 2000 ratings.

Evaluation of selections. Twenty-eight plants that exhibited delayed budbreak in both 1999 and 2000 were selected from the original two populations for further evaluation (Fig. 1). Selection was based primarily on low budbreak ratings, but other factors were also considered. Plants that had not flowered during either 1999 or 2000 were not selected, nor were any plants that appeared weak or unhealthy. A few plants with moderate budbreak ratings, but that flowered heavily both years of the study, were included among the selections.

The 28 selections, 'Carillon', 'Pink Chimes' and 'Emerald Pagoda' were propagated in Summer 2000. Softwood cuttings were dipped for $5 \mathrm{~s}$ in $19.6 \mathrm{~mm}$ indole-3-butyric acid in $50 \%$ ethanol, inserted into a $80 \%$ pine bark : $20 \%$ peatmoss (by volume) mixture and placed under mist. When roots developed, cuttings were transferred to $12.7-\mathrm{cm}$ square pots containing pine bark amended with 6.6 $\mathrm{kg} \cdot \mathrm{m}^{-3} 19 \mathrm{~N}-2.1 \mathrm{P}-7.4 \mathrm{~K}$ Osmocote fertilizer (Scotts-Sierra Horticultural Products Co., Maryville, Ohio), $0.6 \mathrm{~kg} \cdot \mathrm{m}^{-3}$ Micromax (Scotts-Sierra Horticultural Products Co.) and $0.2 \mathrm{~kg} \cdot \mathrm{m}^{-3}$ Epsom salts. Rooted cuttings were maintained in an unheated greenhouse during Winter 2000-01. In Spring 2001, plants were transferred to $11.4 \mathrm{~L}$ containers using the pine bark potting medium described above and grown on a gravel-lined bed in full sun. Plants were irrigated using spray stakes.

In September 2001, the selections and cultivars were planted in the field in a randomized complete block with three single-plant replications. Within-row spacing was $3.6 \mathrm{~m}$ and between-row spacing was $5.5 \mathrm{~m}$. Soil type, fertilization and irrigation were the same as described for the original seedling populations.

Plants were checked each time temperatures dropped below freezing during March andApril 2002, 2003 and 2004. When freeze-damaged foliage was observed, damage was rated 2 to 3 $\mathrm{d}$ later on a scale of 1 to 5 with $1=0 \%, 2=1 \%$ to $10 \%, 3=11 \%$ to $25 \%, 4=26 \%$ to $50 \%$, and $5=>50 \%$ of a plant having damaged foliage. Because only very minor damage occurred to foliage as a result of freezing temperatures during Spring 2004, percent budbreak was used instead of damage ratings to compare plant 
performance. Budbreak ratings were made on 9 Apr., which was the first week that all plants had broken bud, using the scale described for the original seedling population.

The selections were evaluated for variability in growth rate and habit in August 2004. Plant height, plant width (both in-row and perpendicular-to-row), and trunk caliper (15 $\mathrm{cm}$ above ground level) were measured. A growth index, (height + width [in-row] + width [perpendicular-to-row])/3, was calculated for each plant.

Damage ratings, leaf index ratings and plant growth data were analyzed using the General Linear Model Procedure of SigmaStat (SPSS Inc., Chicago). Where data were significant, Tukey's procedure was used to separate means. Because 'Carillon' was the only plant in the study that did not have an upright growth habit, it was not included in the statistical analysis of the growth data.

Temperature data. Daily maximum and minimum temperatures were recorded every 10 min throughout the study using a negative temperature coefficient thermistor in the outdoor weather station of a greenhouse climate control system located in close proximity to the field plots. Growing degree days (GDD) were calculated for days in which the mean temperature exceeded $10{ }^{\circ} \mathrm{C}$ using the following formula: GDD $=\{$ [daily maximum temperature $\left({ }^{\circ} \mathrm{C}\right)+$ daily minimum temperature $\left.\left.\left({ }^{\circ} \mathrm{C}\right)\right] \div 2\right\}-10$. Cumulative GDD were compiled from January 1 until the end of the rating period each year.

\section{Results}

Evaluation of seedling populations. Budbreak was first observed in 1999 on 18 Mar. While half of the plants broke bud during the first two weeks of the evaluation, percent budbreak per plant increased only slightly during this time (Table 1). Warmer temperatures, as reflected in the accumulation of an additional 44 GDD, and a dramatic increase in percent budbreak, occurred between $1 \mathrm{Apr}$. and $8 \mathrm{Apr}$. There were still 11 seedlings, however, that had not broken bud by 8 Apr. Four weeks after the evaluations were initiated, $>75 \%$ of the buds on all plants had broken dormancy.

As indicated by cumulative GDD, the weather in late February and early March 2000 was considerable warmer than during a similar period in 1999 (Table 1). In 2000, the first plant broke bud on 29 Feb., which was 18 $\mathrm{d}$ earlier than in 1999. By 14 Mar. 2000, half of the seedlings experienced budbreak to some extent, although percent budbreak per plant was low. A considerable increase in percent budbreak was observed between 21 Mar. and 28 Mar. 2000. As in 1999, there was a 4-week difference between the first and the last plants to break bud. Despite the different weather conditions, there was a highly significant, but moderate correlation $(r=0.62)$ between mean percent budbreak ratings in 1999 and 2000 (Fig. 1).

Evaluation of selections. Nighttime temperatures of $-6.7^{\circ} \mathrm{C}$ were recorded on $22 \mathrm{Mar}$. 2002, at which time 98 GDD had accumulated since the first of the year. Considerable damage occurred to the foliage of 'Carillon' and 'Emerald Pagoda' (Table 2). Twenty-six of the selections and 'Pink Chimes' had not broken bud at the time of the freeze and were therefore undamaged. One selection, G259-45, suffered moderate freeze damage. Two plants each of 'Emerald Pagoda' and G258-98 died during Summer 2002. Therefore, this cultivar and selection were removed from the 2003 and 2004 statistical analyses.

In 2003 , temperatures dropped to $-3.3{ }^{\circ} \mathrm{C}$ on 30 Mar. Plants were further along in their development at the time of the freeze in 2003 than when the 2002 ratings were made, with 116 GDD having accumulated since the first of the year. Leaf damage ratings of the selections ranged from 1.0 to 4.0 . With the exception of three selections (G258-60, G259-45, and G259-47), all selections had lower damage ratings than 'Carillon'. Statistically, none of the selections exhibited less damage than 'Pink Chimes'.

In 2004 , temperatures dropped to $-2.9^{\circ} \mathrm{C}$ on 23 Mar. Only 89 GDD had accumulated prior to that freeze, and many of the plants had not broken bud. Since only minor damage was noted on the few plants that had leaves, leaf damage was not rated. Because no further freezing temperatures were experienced that winter, percent budbreak was rated on 9 Apr. 2004. At that time, 160 GDD had accumulated since the first of the year. Almost all of the buds on 'Carillon', but less than half of the buds on

Table 1. Vegetative budbreak during Spring 1999 and 2000 of 224 Styrax japonicus seedlings.

\begin{tabular}{lccr}
\hline Date & $\begin{array}{c}\text { Cumulative } \\
\text { GDD }^{z}\end{array}$ & $\begin{array}{c}\text { Budbreak } \\
\text { (mean } \pm \text { SE) }\end{array}$ & $\begin{array}{r}\text { Plants with } \\
\text { leaves (\%) }\end{array}$ \\
\hline 1999 & 75 & $0 \pm 0.01$ & 2.2 \\
18 Mar. & 78 & $0.5 \pm 0.08$ & 24.6 \\
25 Mar. & 85 & $1.3 \pm 0.11$ & 52.0 \\
1 Apr & 129 & $3.6 \pm 0.10$ & 94.6 \\
8 Apr. & 165 & $4.9 \pm 0.03$ & 100.0 \\
15 Apr. & 205 & $5.0 \pm 0$ & 100.0 \\
22 Apr. & & & 0.4 \\
2000 & 66 & $0 \pm 0.01$ & 5.8 \\
29 Feb. & 79 & $0 \pm 0.01$ & 52.7 \\
7 Mar. & 101 & $1.0 \pm 0.08$ & 85.3 \\
14 Mar. & 109 & $2.4 \pm 0.11$ & 100.0 \\
28 Mar. & 132 & $4.2 \pm 0.08$ & 100.0 \\
\hline Apr. & 149 & $5.0 \pm 0.01$ & \\
\hline
\end{tabular}

${ }^{\mathrm{z}} \mathrm{GDD}=$ Growing degree days $=\left\{\right.$ [daily maximum temperature $\left({ }^{\circ} \mathrm{C}\right)+$ daily minimum temperature $\left.\left({ }^{\circ} \mathrm{C}\right)\right]$ $\div 2\}-10$ for days in which the mean daily temperature was $>10^{\circ} \mathrm{C}$.

${ }^{\mathrm{y}}$ Budbreak rated on a scale of 0 to 5 , where $0=0 \%, 1=1 \%$ to $10 \%, 2=11 \%$ to $25 \%, 3=26 \%$ to $50 \%, 4$ $=51 \%$ to $75 \%$, and $5=76 \%$ to $100 \%$ of the buds having broken dormancy.

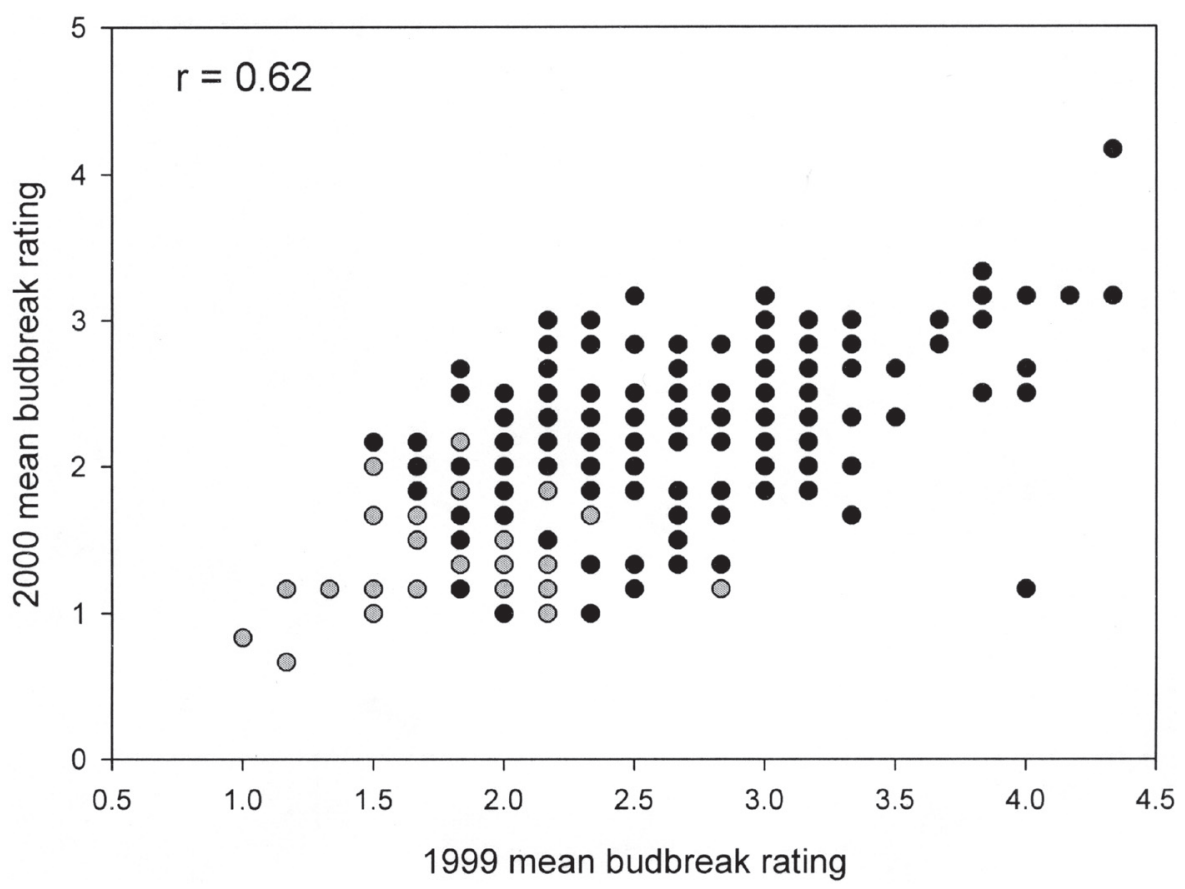

Fig. 1. Relationship between mean budbreak ratings of 224 Styrax japonicus seedlings in 1999 and 2000. Budbreak rated on a scale of 0 to 5 , where $0=0 \%, 1=1 \%$ to $10 \%, 2=11 \%$ to $25 \%, 3=26 \%$ to $50 \%$, $4=51 \%$ to $75 \%$, and $5=76 \%$ to $100 \%$ of the buds having broken dormancy. Ratings made weekly from 18 Mar. to 22 Apr. 1999 and from 29 Feb. to 4 Apr. 2000. Weekly ratings averaged to give mean budbreak rating. Plants selected for further evaluation are indicated in gray. Many data points represent multiple plants. 
Table 2. Spring freeze damage, leaf development and growth measurements of Styrax japonicus selections and cultivars.

\begin{tabular}{|c|c|c|c|c|c|c|c|}
\hline \multirow[b]{2}{*}{ Plant } & \multicolumn{2}{|c|}{ Leaf damage ${ }^{z y}$} & \multirow{2}{*}{$\begin{array}{c}\text { Budbreak } \\
9 \text { Apr. } 2004\end{array}$} & \multirow{2}{*}{$\begin{array}{c}\mathrm{Ht} \\
(\mathrm{cm})\end{array}$} & \multirow{2}{*}{$\begin{array}{l}\text { Width } \\
\text { (cm) }\end{array}$} & \multirow{2}{*}{$\begin{array}{l}\text { Caliper } \\
(\mathrm{mm})\end{array}$} & \multirow{2}{*}{$\begin{array}{l}\text { Growth } \\
\text { index }\end{array}$} \\
\hline & 25 Mar. 2002 & 1 Apr. 2003 & & & & & \\
\hline G258-22 & $1.0 \mathrm{c}$ & $2.0 \mathrm{bcd}$ & $2.0 \mathrm{bcd}$ & $310 \mathrm{ab}$ & $148 \mathrm{a}-\mathrm{e}$ & $68.7 \mathrm{abc}$ & $202 \mathrm{abcd}$ \\
\hline G258-33 & $1.0 \mathrm{c}$ & $1.3 \mathrm{bcd}$ & $2.0 \mathrm{bcd}$ & $268 \mathrm{a}-\mathrm{e}$ & $151 \mathrm{a}-\mathrm{e}$ & $67.9 \mathrm{abc}$ & $190 \mathrm{a}-\mathrm{e}$ \\
\hline G258-34 & $1.0 \mathrm{c}$ & $2.4 \mathrm{bcd}$ & $2.0 \mathrm{bcd}$ & $323 \mathrm{ab}$ & $203 \mathrm{ab}$ & $70.0 \mathrm{abc}$ & $244 \mathrm{a}$ \\
\hline G258-60 & $1.0 \mathrm{c}$ & $2.9 \mathrm{abcd}$ & $1.5 \mathrm{~cd}$ & $227 \mathrm{a}-\mathrm{e}$ & $151 \mathrm{a}-\mathrm{e}$ & $44.7 \mathrm{~cd}$ & $177 \mathrm{a}-\mathrm{e}$ \\
\hline G258-65 & $1.7 \mathrm{bc}$ & $2.3 \mathrm{bcd}$ & $2.0 \mathrm{bcd}$ & $244 \mathrm{a}-\mathrm{e}$ & 129 cde & $62.0 \mathrm{abcd}$ & 168 bcde \\
\hline G258-76 & $1.0 \mathrm{c}$ & $2.3 \mathrm{bcd}$ & $2.3 \mathrm{bcd}$ & $331 \mathrm{a}$ & $152 \mathrm{a}-\mathrm{e}$ & $65.3 \mathrm{abc}$ & $211 \mathrm{abcd}$ \\
\hline G258-78 & $1.0 \mathrm{c}$ & $2.7 \mathrm{bcd}$ & $2.0 \mathrm{bcd}$ & $230 \mathrm{a}-\mathrm{e}$ & $155 \mathrm{a}-\mathrm{e}$ & 60.4 abcd & $180 \mathrm{a}-\mathrm{e}$ \\
\hline G258-84 & $1.0 \mathrm{c}$ & $1.7 \mathrm{bcd}$ & $2.0 \mathrm{bcd}$ & 278 abcd & $172 \mathrm{abcd}$ & $62.6 \mathrm{abcd}$ & $207 \mathrm{abcd}$ \\
\hline G258-87 & $1.0 \mathrm{c}$ & $1.7 \mathrm{bcd}$ & $2.0 \mathrm{bcd}$ & $260 \mathrm{a}-\mathrm{e}$ & $168 \mathrm{abcd}$ & $64.7 \mathrm{abc}$ & $198 \mathrm{a}-\mathrm{e}$ \\
\hline G258-90 & $1.0 \mathrm{c}$ & $1.7 \mathrm{bcd}$ & $2.0 \mathrm{bcd}$ & $336 \mathrm{a}$ & $180 \mathrm{abc}$ & $64.7 \mathrm{abc}$ & $232 a b$ \\
\hline G258-96 & $1.0 \mathrm{c}$ & $1.7 \mathrm{bcd}$ & $2.0 \mathrm{bcd}$ & $335 \mathrm{a}$ & $164 \mathrm{a}-\mathrm{e}$ & $65.6 \mathrm{abc}$ & $220 \mathrm{abc}$ \\
\hline G258-98 & $1.0 \mathrm{c}$ & --- & --- & --- & --- & --- & --- \\
\hline G258-103 & $1.0 \mathrm{c}$ & $2.0 \mathrm{bcd}$ & $2.0 \mathrm{bcd}$ & $303 \mathrm{abc}$ & $180 \mathrm{abc}$ & $73.5 \mathrm{a}$ & $221 \mathrm{abc}$ \\
\hline G258-115 & $1.0 \mathrm{c}$ & $1.3 \mathrm{bcd}$ & $1.3 \mathrm{~d}$ & $264 \mathrm{a}-\mathrm{e}$ & 124 cde & $61.4 \mathrm{abcd}$ & 170 bcde \\
\hline G258-117 & $1.0 \mathrm{c}$ & $1.7 \mathrm{bcd}$ & $1.7 \mathrm{~cd}$ & 297 abcd & 131 bcde & $56.7 \mathrm{abcd}$ & $186 \mathrm{a}-\mathrm{e}$ \\
\hline G259-16 & $1.0 \mathrm{c}$ & $2.7 \mathrm{bcd}$ & $2.7 \mathrm{bcd}$ & $160 \mathrm{e}$ & 124 cde & $46.4 \mathrm{~cd}$ & $136 \mathrm{e}$ \\
\hline G259-25 & $1.0 \mathrm{c}$ & $2.4 \mathrm{bcd}$ & $2.7 \mathrm{bcd}$ & 203 bcde & $104 \mathrm{e}$ & $42.1 \mathrm{~d}$ & 137 e \\
\hline G259-26 & $1.0 \mathrm{c}$ & $1.0 \mathrm{bcd}$ & $1.7 \mathrm{~cd}$ & $302 \mathrm{abc}$ & $177 \mathrm{abc}$ & $58.6 \mathrm{abcd}$ & 219 abc \\
\hline G259-36 & $1.0 \mathrm{c}$ & $2.0 \mathrm{bcd}$ & $2.0 \mathrm{bcd}$ & $221 \mathrm{a}-\mathrm{e}$ & 130 bcde & $54.9 \mathrm{abcd}$ & 160 bcde \\
\hline G259-45 & $2.3 \mathrm{~b}$ & $4.0 \mathrm{ab}$ & $2.7 \mathrm{bcd}$ & 217 bcde & $179 \mathrm{abc}$ & $63.5 \mathrm{abcd}$ & $192 \mathrm{a}-\mathrm{e}$ \\
\hline G259-47 & $1.0 \mathrm{c}$ & $3.7 \mathrm{abc}$ & $3.0 \mathrm{bc}$ & $270 \mathrm{a}-\mathrm{e}$ & $105 \mathrm{de}$ & $49.5 \mathrm{bcd}$ & 160 bcde \\
\hline G259-51 & $1.0 \mathrm{c}$ & $2.0 \mathrm{bcd}$ & $3.0 \mathrm{bc}$ & $194 \mathrm{de}$ & $127 \mathrm{cde}$ & $47.5 \mathrm{~cd}$ & $149 \mathrm{de}$ \\
\hline G259-53 & $1.0 \mathrm{c}$ & $1.3 \mathrm{bcd}$ & $2.0 \mathrm{bcd}$ & 209 bcde & $151 \mathrm{a}-\mathrm{e}$ & $39.9 \mathrm{~d}$ & $171 \mathrm{a}-\mathrm{e}$ \\
\hline G259-57 & $1.0 \mathrm{c}$ & $2.3 \mathrm{bcd}$ & $2.0 \mathrm{bcd}$ & 197 cde & 127 cde & $53.2 \mathrm{abcd}$ & $150 \mathrm{de}$ \\
\hline G259-68 & $1.0 \mathrm{c}$ & $1.3 \mathrm{bcd}$ & $2.0 \mathrm{bcd}$ & 287 abcd & 115 cde & $58.0 \mathrm{abcd}$ & $172 \mathrm{a}-\mathrm{e}$ \\
\hline G259-77 & $1.0 \mathrm{c}$ & $2.3 \mathrm{bcd}$ & $3.0 \mathrm{bc}$ & $288 \mathrm{abcd}$ & $107 \mathrm{de}$ & $54.1 \mathrm{abcd}$ & 168 bcde \\
\hline G259-91 & $1.0 \mathrm{c}$ & $1.7 \mathrm{bcd}$ & $2.7 \mathrm{bcd}$ & 299 abcd & $204 \mathrm{a}$ & $71.8 \mathrm{ab}$ & $236 \mathrm{a}$ \\
\hline G259-94 & $1.0 \mathrm{c}$ & $1.4 \mathrm{bcd}$ & $1.5 \mathrm{~cd}$ & $225 \mathrm{a}-\mathrm{e}$ & $120 \mathrm{cde}$ & $53.9 \mathrm{abcd}$ & $155 \mathrm{cde}$ \\
\hline Carillon & $3.3 \mathrm{a}$ & $5.0 \mathrm{a}$ & $5.0 \mathrm{a}$ & --- & --- & --- & --- \\
\hline Pink Chimes & $1.0 \mathrm{c}$ & $4.0 \mathrm{ab}$ & $3.5 \mathrm{ab}$ & $261 \mathrm{a}-\mathrm{e}$ & $160 \mathrm{a}-\mathrm{e}$ & 54.8 abcd & $194 \mathrm{a}-\mathrm{e}$ \\
\hline Emerald Pagoda & $4.0 \mathrm{a}$ & --- & --- & --- & --- & --- & --- \\
\hline
\end{tabular}

${ }^{\mathrm{z}}$ Leaf damage rated on a scale of 1 to 5 , where $1=0 \%, 2=1 \%$ to $10 \%, 3=11 \%$ to $25 \%, 4=26 \%$ to $50 \%$, and $5=>50 \%$ of the foliage damaged; ratings made 2 to $3 \mathrm{~d}$ after damaging freeze. Budbreak rated on a scale of 0 to 5 , where $0=0 \%, 1=1 \%$ to $10 \%, 2=11 \%$ to $25 \%, 3=26 \%$ to $50 \%, 4=51 \%$ to $75 \%$, and $5=$ $76 \%$ to $100 \%$ of the buds having broken dormancy. Width $=$ mean of in-row and perpendicular-to-row width measurements. Growth index $=($ height + width, in row + width, perpendicular to row $) / 3$.

${ }^{\mathrm{y}}$ Values within a column followed by the same letter do not differ significantly according to Tukey's test $(P \leq 0.05)$; $\mathrm{n}=3$.

'Pink Chimes' had broken dormancy on that date. Percent budbreak was greater in 'Carillon' than in any of the selections, but only five selections (G258-60, G258-115, G258-117, G259-26 and G259-94) were slower to break bud than 'Pink Chimes'.

Variation in growth rate and plant shape was observed among the selections (Table 2). Plant height ranged from 160 to $336 \mathrm{~cm}$. These was also a 2-fold difference between the widest and narrowest selections. Caliper ranged from 39.9 $\mathrm{mm}$ to $73.5 \mathrm{~mm}$. Growth index, which took into account both height and width, varied from 136 to 244. For all measurements, 'Pink Chimes' was not significantly different from most of the selections.

\section{Discussion}

Buds of most temperate-zone deciduous trees and shrubs undergo a period of dormancy during the winter. Endodormancy involves factors within the bud itself and occurs during winter (Lang et al., 1987). Buds are not released from the endodormant state until a chilling requirement has been met (Saure, 1985; Sorensen, 1983). Ecodormancy is controlled by environmental factors and usually occurs in late winter and spring when dormancy is imposed by temperatures unfavorable for growth.

Time of budbreak is an important factor in nursery crop production. Early budbreak can result in a longer grower season and increased growth. However, in S. japonicus, early budbreak often leads to spring freeze damage to foliage. This study demonstrated that there is genetic variation within $S$. japonicus for time of vegetative budbreak. Even though strikingly different weather conditions were encountered in 1999 and 2000, there was good consistency between years as to whether a plant broke bud early or late in relation to the rest of the seedlings. Plants with even greater diversity in time of budbreak might be identified by evaluating larger populations from a wide range of native habitats, as provenance effects on time of budbreak have been found in red maple (Townsend, 1977) and pecan (Wood et al., 1998).

Replicated trials of plants that were selected on the basis of late budbreak indicated that the selections were considerably less susceptible to spring freeze damage than two popular cultivars, 'Emerald Pagoda' and 'Carillon'. We are continuing the evaluation of plants identified in this study as having delayed budbreak to determine if they merit introduction as cultivars. Variation in growth measurements was observed among the selections, providing an opportunity to select for plants with different growth rates and forms. Using the genetic variability for physiological traits observed in this study and among $S$. japonicus growing in native stands (Meyer, 1992; Raulston, 1991) should lead to the development of cultivars with less susceptibility to damage from spring freezes and expand the use of this attractive tree in the landscape.

Further work is needed to identify the basis for the genetic variation in time of budbreak in $S$. japonicus. Genetic variation in chilling requirements needed to release plants from an endodormant state has been observed in a number of genera (Hauagge and Cummins, 1991; Wilson et al., 2002; Wood et al., 1998). Wilson et al. (2002) noted differences among red (Acer rubrum) and freeman (A. × freemanii E. Murr. [rubrum $\times$ saccharinum] maple cultivars not only for the number of hours below $7{ }^{\circ} \mathrm{C}$ needed to break endodormany, but also for the number of hours above $22^{\circ} \mathrm{C}$ needed to initiate budbreak after the chilling requirement was met. While budbreak in $S$. japonicus appeared to be influenced by warm temperatures, as reflected in cumulative GDD, number of chilling hours accumulated during winter 1998-99 and 1999-2000 were not available for comparison. If genetic variation for both endodormancy and ecodormancy requirements exists in $S$. japonicus, then it may be possible to select plants suited for specific environments. For warmer climates, a low chilling unit requirement would ensure that endodormancy requirements are met even during mild winters while a high ecodormancy requirement would prevent budbreak until weather conditions were suitable for continued growth. In contrast, plants with a high chilling and a low heat unit requirement would perform 
better in colder areas of the country. Plants identified in this study as differing in time of budbreak can serve as the basis for conducting a more detailed study on the genetic variation in dormancy requirements of $S$. japonicus.

\section{Literature Cited}

Dirr, M.A. 1998. Manual of woody landscape plants. Stipes Publishing, Champaign, Ill.

Hauagge, R. and J.N. Cummins. 1991. Genetics of length of dormancy period in Malus vegetative buds. J. Amer. Soc. Hort. Sci. 116:121-126.

J. Frank Schmidt and Son Company. 2004. Snowbells ring in the summer season. 26 Oct. 2004.
$<$ http://www.jfschmidt.com/articles/styrax_japonicus/>.

Lang, G.A., J.D. Early, G.C. Martin, and R.L. Dranell. 1987. Endo-, para-, and eco-dormancy physiological terminology and classification for dormancy research. HortScience 22:371-377.

Meyer, P. 1992. The snowbells of Korea. Arnoldia 52:2-8.

Raulston, J.C. 1991. Styrax evaluations in the NCSU Arboretum. Proc. Southern Nursery Res. Conf. 36:305-310

Saure, M. 1985. Dormancy release in deciduous fruit trees. Hort. Rev. 7:239-300.

Sorensen, F.C. 1983. Relationship between logarithms of chilling period and germination or bud flush rate is linear for many tree species. For. Sci. 29:237-240

Townsend, A.M. 1977. Characteristics of red maple progenies from different geographic areas. J. Amer. Soc. Hort. Sci. 102:461-466.

Tubesing, C.E. 1990. Styrax and ambrosia beetles. Amer. Nurseryman. 172:145.

Wilson, B.C., J.L. Sibley, J.E.Altland, E.H. Simonne, andD.J. Eakes. 2002. Chilling and heat unit levels affect foliar budbreak of selected red and freeman maple cultivars. J. Arboricult. 38:148-151.

Wood, B.W., L. J. Grauke, and J.A. Payne. 1998. Provenance variation in pecan. J. Amer. Soc. Hort. Sci. 123:1023-1028. 